\title{
A Comparative Study of Sino-Kazakhstan Service Trade From the Perspective of Management
}

\author{
Yuan Fang 1, a \\ School of Economics, Shanghai University,99 Shangda Road, \\ ${ }^{1}$ Baoshan District, Shanghai, China \\ a512684495@qq.com
}

\begin{abstract}
Keywords: Management; Sino-Kazakhstan service trade; RCA index; CA index
\end{abstract}
\begin{abstract}
This paper deals with trade between Sino-Kazakhstan through the Revealed Comparative Advantage Competitive (RCA), and the Net Export Revealed Comparative Advantage Index (NRCA). The analysis of competition and complementarity shows that the comparative advantage industries in Sino- Kazakhstan are different. Generally speaking, the two countries have strong competitive advantages in the traditional trade field, but the development of emerging service trade is relatively slow. Therefore, it provides relevant countermeasures and suggestions for deepening Sino-Kazakhstan service trade cooperation.
\end{abstract}

\section{Introduction}

Since Kazakhstan declared independence and formally established diplomatic relations with China, thanks to the geographical advantages of the two countries and the complementary advantages in the economic and trade fields, the trade cooperation between China and Kazakhstan has maintained rapid development. With the continuous development of trade in goods, the service trade industry has become a hot issue of concern to both China and Kazakhstan. Under this background, systematic and in-depth study and analysis of the status quo of China's and Kazakhstan's service trade has important practical and enlightening significance for promoting China's economic restructuring, realizing the upgrading of industrial structure, and improving the quality of trade between the two countries. This paper mainly analyzes the China-Kazakhstan Display Comparative Advantage Index (RCA) and the Net Export Display Comparative Advantage Index (NRCA) to analyze the competition and complementarity of service trade between China and Kazakhstan, and seeks to provide theoretical guidance for the cooperation and trade cooperation between the two sides.

\section{Revealed Comparative Advantage Competitive (RCA)}

Vollratlh proposed the method of calculating RCA is to subtract the comparative advantage of the industry's imports from the comparative advantage of the industry's exports. It reflected the real competitive advantage of the country's industry. Its calculation formula is as follows:

$$
\mathrm{CA}_{\mathrm{ij}}=\mathrm{RCA}_{\mathrm{ij}}^{\mathrm{x}}-\mathrm{RCA}_{\mathrm{ij}}^{\mathrm{m}}
$$

$\mathrm{RCA}_{\mathrm{ij}}^{\mathrm{x}}$ represents the Revealed Export Comparative Advantage Index, RCA $\mathrm{ij}_{\mathrm{ij}}^{\mathrm{m}}$ represents the Revealed Import Comparative Advantage Index. If a country's RCA index is greater than 0, it indicates that the country's service trade has a comparative advantage; if the CA index is less than 0 , it means that the country's service trade does not have a comparative advantage. The higher the index, the stronger the international competitiveness of the country's service trade; on the contrary, the lower the index, the weaker the international competitiveness of the country's service trade. 
Table 1 Comparative Advantage Index of China and Kazakhstan in 2006-2015

\begin{tabular}{|c|c|c|c|c|c|c|c|c|c|c|c|}
\hline Year & $\begin{array}{l}\text { Co } \\
\text { unt } \\
\text { ry }\end{array}$ & $\begin{array}{l}\text { Transp } \\
\text { ortatio } \\
\mathrm{n}\end{array}$ & $\begin{array}{l}\text { Tuoris } \\
\mathrm{m}\end{array}$ & $\begin{array}{l}\text { Com } \\
\text { munic } \\
\text { ation }\end{array}$ & $\begin{array}{l}\text { Constru } \\
\text { ction }\end{array}$ & $\begin{array}{l}\text { Insuranc } \\
\mathrm{e}\end{array}$ & $\begin{array}{l}\text { Financ } \\
\mathrm{e}\end{array}$ & $\begin{array}{l}\text { Comp } \\
\text { uter\&i } \\
\text { nform } \\
\text { ation }\end{array}$ & $\begin{array}{l}\text { Use } \\
\text { and } \\
\text { license } \\
\text { fees }\end{array}$ & $\begin{array}{l}\text { Other } \\
\text { busine } \\
\text { ss }\end{array}$ & $\begin{array}{l}\text { Cultur } \\
\text { e\&ent } \\
\text { ertain } \\
\text { ment }\end{array}$ \\
\hline \multirow[b]{2}{*}{2006} & $\mathrm{C}$ & -0.46 & 0.52 & 0.02 & 0.42 & -2.84 & -0.12 & 0.41 & -1.03 & 0.49 & 0.03 \\
\hline & $\mathrm{K}$ & 1.52 & 0.89 & 0.83 & 0.06 & -12.74 & -0.48 & -0.17 & -0.09 & -0.92 & -0.16 \\
\hline \multirow[b]{2}{*}{2007} & $\mathrm{C}$ & -0.32 & 0.32 & 0.06 & 0.88 & -2.55 & -0.04 & 0.49 & -1.00 & 0.41 & 0.15 \\
\hline & $\mathrm{K}$ & 1.35 & 0.85 & 0.74 & -15.07 & -0.36 & 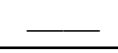 & -0.16 & -0.10 & -0.80 & -0.15 \\
\hline \multirow[b]{2}{*}{2008} & $\mathrm{C}$ & -0.22 & 0.22 & 0.05 & 1.62 & -2.38 & -0.02 & 0.54 & -0.97 & 0.31 & 0.14 \\
\hline & $\mathrm{K}$ & 1.24 & 0.61 & 0.54 & -10.67 & -0.14 & $\bar{L}$ & -0.14 & $\bar{L}$ & -0.89 & -0.24 \\
\hline \multirow[b]{2}{*}{2009} & $\mathrm{C}$ & -0.52 & 0.14 & 0.07 & 1.27 & -2.06 & -0.02 & 0.66 & -0.92 & 0.55 & -0.11 \\
\hline & $\mathrm{K}$ & 1.61 & 0.54 & 0.70 & -7.17 & -0.15 & 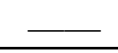 & -0.21 & 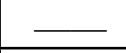 & -1.17 & -0.30 \\
\hline \multirow[b]{2}{*}{2010} & $\mathrm{C}$ & -0.55 & -0.01 & 0.07 & 3.37 & -2.23 & 0.02 & 0.95 & -0.99 & 0.68 & -0.13 \\
\hline & $\mathrm{K}$ & 1.82 & 0.63 & 0.44 & -7.55 & -0.32 & - & -0.14 & 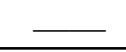 & -1.80 & -0.33 \\
\hline \multirow[b]{2}{*}{2011} & $\mathrm{C}$ & -0.62 & -0.15 & 0.19 & 3.57 & -2.02 & 0.04 & 1.10 & -0.84 & 0.73 & -0.10 \\
\hline & $\mathrm{K}$ & 1.47 & 0.62 & 0.42 & -9.10 & -0.33 & 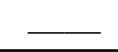 & -0.12 & 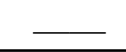 & -1.33 & -0.49 \\
\hline \multirow[b]{2}{*}{2012} & $\mathrm{C}$ & -0.51 & -0.48 & 0.17 & 2.98 & -1.79 & 0.08 & 1.36 & -1.02 & 0.92 & -0.15 \\
\hline & $\mathrm{K}$ & 1.57 & 0.70 & 0.49 & -12.43 & 0.09 & -0.28 & -0.05 & 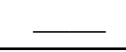 & -1.27 & -0.49 \\
\hline \multirow[b]{2}{*}{2013} & $\mathrm{C}$ & -0.42 & -0.52 & - & 2.72 & -1.50 & 0.16 & 1.64 & -1.05 & 0.90 & -0.17 \\
\hline & $\mathrm{K}$ & 1.56 & 0.63 & - & -10.45 & 0.10 & -0.53 & -0.15 & -0.23 & 0.00 & -0.72 \\
\hline \multirow[b]{2}{*}{2014} & $\mathrm{C}$ & -0.36 & -0.76 & - & 3.38 & -1.24 & 0.23 & 1.36 & -0.86 & 0.97 & -0.16 \\
\hline & $\mathrm{K}$ & 1.97 & 0.22 & - & -7.13 & 0.18 & -0.25 & -0.23 & -0.24 & 0.00 & -0.80 \\
\hline \multirow[b]{2}{*}{2015} & $\mathrm{C}$ & -0.08 & -0.82 & - & 2.46 & -0.04 & 0.10 & - & -0.58 & 0.75 & -0.17 \\
\hline & $\mathrm{K}$ & 2.10 & 0.22 & - & -7.28 & 0.27 & -0.31 & -0.49 & -0.20 & 0.00 & -0.94 \\
\hline
\end{tabular}

Source: UN COMTRAD calculation available

From Table 3 we can see that the CA index of China's transportation industry has been negative for ten consecutive years, but the negative value has a decreasing trend. This shows that China's transportation service industry does not have a comparative advantage. The Kazakhstan transport industry CA index has been greater than 0 for ten consecutive years and is on an increasing trend year by year. The CA index of China's and Kazakhstan's tourism service industry has been declining year by year. China's CA index changed from positive to negative in 2010, and its international competitiveness has become weaker in the past five years. In the communication service industry, both China and Kazakhstan have comparative advantages. From the index value, Kazakhstan has a higher comparative advantage than China. China has obvious comparative advantages in the construction industry, with values maintained between 2 and 3, while Kazakhstan has obvious comparative disadvantages. In the emerging service industries such as insurance, finance, and computer and information, China and Kazakhstan do not have comparative advantages. It is worth mentioning that the computer and information, other business services industry China's CA index are greater than 0 , showing a comparative advantage.

\section{Net Export Revealed Comparative Advantage Index (NRCA)}

In order to reflect the impact of imports on export competitiveness, Balassa also proposed an improved index of comparative advantage in 1989, using the proportion of a country's exports of a certain industry in total exports and the country's imports of the industry in total imports. The difference in the ratio indicates the trade competitive advantage of the industry. This index is called the "net export revealed comparative advantage index". Calculated as follows: 


$$
\mathrm{NRCA}_{\mathrm{ij}}=\left(\mathrm{X}_{\mathrm{ij}} / \mathrm{X}_{\mathrm{i}}\right) /\left(\mathrm{M}_{\mathrm{ij}} / \mathrm{M}_{\mathrm{i}}\right)
$$

$\mathrm{X}_{\mathrm{ij}}$ represents the export of $\mathrm{i}$ country $\mathrm{j}$ products, $\mathrm{X}_{\mathrm{i}}$ represents the total export of country $\mathrm{i}$, $\mathrm{M}_{\mathrm{ij}}$ represents the import of $\mathrm{i}$ country $\mathrm{j}$ products, $\mathrm{M}_{\mathrm{i}}$ is the total import of country $\mathrm{i}$. An index value greater than 0 indicates a competitive advantage, an index value less than 0 indicates a competitive disadvantage, and an index value equal to 0 indicates trade self-balance. The net export-displayed comparative advantage index excludes the influence of intra-industry trade or division of labor, reflecting the impact of both import and export. Therefore, using the index to judge the international competitiveness of the industry is more realistic than other indexes. The higher the index value, the stronger the international competitiveness; the lower the index value, the weaker the international competitiveness. If we consider the impact of trade barriers.

Table 2 2006-2015 China-Kazakhstan Service Trade NRCA Index

\begin{tabular}{|c|c|c|c|c|c|c|c|c|c|c|c|}
\hline Year & Court & $\operatorname{tran}$ & tour & tele & cons & insur & Fina & Comp & Lice & Busi & Entert \\
\hline \multirow[b]{2}{*}{2006} & $\mathrm{C}$ & -0.11 & 0.13 & 0.00 & 0.01 & -0.08 & -0.01 & 0.01 & -0.06 & 0.11 & 0.00 \\
\hline & $\mathrm{K}$ & 0.37 & 0.22 & 0.02 & 0.00 & -0.37 & - & -0.01 & 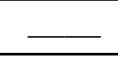 & -0.21 & 0.00 \\
\hline \multirow[b]{2}{*}{2007} & $\mathrm{C}$ & -0.08 & 0.08 & 0.00 & 0.02 & -0.07 & 0.00 & 0.02 & -0.06 & 0.10 & 0.00 \\
\hline & $\mathrm{K}$ & 0.33 & 0.20 & 0.02 & -0.37 & -0.01 & - & -0.01 & $\bar{C}$ & -0.19 & 0.00 \\
\hline \multirow[b]{2}{*}{2008} & $\mathrm{C}$ & -0.06 & 0.05 & 0.00 & 0.04 & -0.07 & 0.00 & 0.02 & -0.06 & 0.07 & 0.00 \\
\hline & $\mathrm{K}$ & 0.31 & 0.14 & 0.01 & -0.28 & 0.00 & - & -0.01 & 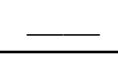 & -0.21 & 0.00 \\
\hline \multirow[b]{2}{*}{2009} & $\mathrm{C}$ & -0.11 & 0.03 & 0.00 & 0.04 & -0.06 & 0.00 & 0.03 & -0.07 & 0.14 & 0.00 \\
\hline & $\mathrm{K}$ & 0.34 & 0.12 & 0.02 & -0.20 & 0.00 & - & -0.01 & 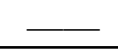 & -0.29 & 0.00 \\
\hline \multirow[b]{2}{*}{2010} & $\mathrm{C}$ & -0.12 & 0.00 & 0.00 & 0.06 & -0.07 & 0.00 & 0.04 & -0.06 & 0.14 & 0.00 \\
\hline & $\mathrm{K}$ & 0.39 & 0.13 & 0.01 & -0.14 & -0.01 & - & -0.01 & 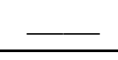 & -0.38 & 0.00 \\
\hline \multirow[b]{2}{*}{2011} & $\mathrm{C}$ & -0.13 & -0.03 & 0.00 & 0.06 & -0.06 & 0.00 & 0.05 & -0.06 & 0.17 & 0.00 \\
\hline & $\mathrm{K}$ & 0.32 & 0.13 & 0.01 & -0.16 & -0.01 & - & -0.01 & 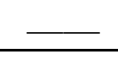 & -0.30 & 0.00 \\
\hline \multirow[b]{2}{*}{2012} & $\mathrm{C}$ & -0.10 & -0.10 & 0.00 & 0.05 & -0.06 & 0.00 & 0.06 & -0.06 & 0.20 & 0.00 \\
\hline & $\mathrm{K}$ & 0.32 & 0.15 & 0.01 & -0.21 & 0.00 & -0.01 & 0.00 & 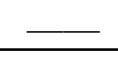 & -0.27 & 0.00 \\
\hline \multirow[b]{2}{*}{2013} & $\mathrm{C}$ & -0.08 & -0.11 & - & 0.05 & -0.05 & 0.01 & 0.07 & -0.06 & 0.17 & 0.00 \\
\hline & $\mathrm{K}$ & 0.30 & 0.13 & - & -0.18 & 0.00 & -0.02 & -0.01 & -0.01 & 0.00 & -0.01 \\
\hline \multirow[b]{2}{*}{2014} & $\mathrm{C}$ & -0.07 & -0.16 & 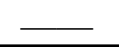 & 0.06 & -0.04 & 0.01 & 0.07 & -0.06 & 0.19 & 0.00 \\
\hline & $\mathrm{K}$ & 0.38 & 0.05 & - & -0.13 & 0.01 & -0.01 & -0.01 & -0.02 & 0.00 & -0.01 \\
\hline \multirow[b]{2}{*}{2015} & $\mathrm{C}$ & -0.01 & -0.19 & 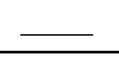 & 0.04 & 0.00 & 0.00 & - & -0.04 & 0.14 & 0.00 \\
\hline & K & 0.39 & 0.05 & 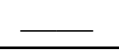 & -0.12 & 0.01 & -0.01 & -0.01 & -0.02 & 0.00 & -0.01 \\
\hline
\end{tabular}

Source: UN COMTRAD calculation available

After removing the influence of intra-industry trade or division of labor, we can see that China's industries with a net export-displayed comparative advantage are architecture, computers and information and other businesses, and trade self-balancing in the communications, finance and personal culture and entertainment industries. There is a competitive disadvantage in the transportation, insurance and proprietary rights use and licensing services industries. Kazakhstan has obvious competitive advantages in transportation and tourism services. It also has certain competitive disadvantages in construction services, and basically maintains trade self-balance in other service industries. 


\section{Suggestions on deepening the cooperation between Sino-Kazakhstan in service trade}

Through the above indicators, we can clearly see that China and Kazakhstan have different comparative advantages in service trade, China has obvious comparative advantages in the construction services industry, and Kazakhstan has a comparative advantage in the transportation industry. Although China's competitive advantage in emerging services is not obvious, the competitiveness of the computer and information industry and other commercial industries is still above the world average. In addition to the strong competitiveness of the communications industry, Kazakhstan's other emerging service sectors are developing very slowly and are at a relatively disadvantageous position. Therefore, China and Kazakhstan should give full play to their respective competitive advantages, improve resource utilization, and optimize resource allocation. This will not only rationalize the structure of import and export services, but also promote the common development of the two economies.

It is necessary to promote the coordination of trade in goods and services, further adjust the development strategy of service trade, and promote the service trade cooperation between the two sides with the help of the "Belt and Road". China's opening to the west is conducive to the development of Kazakhstan, and the two sides should vigorously promote interconnection. Promote cooperation in the fields of logistics, transportation, communications, etc., and build a good port of Horgos, which will create more convenience for service trade between the two countries.

\section{References}

[1] Ernst B. Hass. The Uniting of Europe [M]. Stanford: Stanford University Press,1958,p68

[2] Anthony J. Venables. Winners and Losers from Regional Integration Agreements[M]. The Economic Journal,(October)2003,113,p747-761

[3] W. M. Corden. Economies of scale and customs union theory[J]. The Journal of Political Economy,1972,80(3),p65-47

[4] Zhang Henglong, Zhou Yuancheng. Research on Sino-Kazakhstan Trade Liberalization under the "Belt and Road" Strategy[J]. Journal of Xinjiang Normal University(Philosophy and Social Sciences), 2015, (04): 76-84.

[5] Cui Yuan, Sun Xiangjun. Research on the Development Countermeasures of China-Kazakhstan Railway Passage[J]. Comprehensive Transportation, 2015, (12): 37-40.

[6] Wang Ying. Research on the construction and development of China-Kazakhstan cross-border tourism cooperation zone under the background of "Silk Road Economic Belt" [D]. Xinjiang University of Finance and Economics, 2016.

[7] Lang Wei. Research on Financial Development of the Sino-Khalkhas International Border Cooperation Center [D]. Xinjiang University of Finance and Economics, 2016.

[8] Wang Haiyan. China-Kazakhstan Free Trade Area: Opportunities, Challenges and Prospects[J]. International Economic Cooperation, 2009, Issue 11: 33-38

[9] Yang Huan. Research on service trade cooperation between China and Kazakhstan [D]. Xinjiang University, 2015. 